\title{
Epidemiology of Selected Diseases Related to Air Pollution in Krakow
}

\section{Agnieszka Petryk ${ }^{1}$}

1 Department of Regional Economics, Cracow University of Economics, ul. Rakowicka 27, 31-510 Kraków, Poland, e-mail: agnieszka.petryk@uek.krakow.pl

\begin{abstract}
Excessive concentrations of smog toxicants constitute a critical factor influencing the health quality of inhabitants of urban agglomerations. The exposure to elevated concentrations of suspended particulate matter, sulfur dioxide $\left(\mathrm{SO}_{2}\right)$, nitrogen dioxide $\left(\mathrm{NO}_{2}\right)$ and carbon monoxide $(\mathrm{CO})$ is associated with an increase of adverse health effects. Prolonged exposure to air pollution, especially from low emission, may be linked not only to a greater risk of developing cancer of the respiratory system, or cardiovascular morbidity but also to the increased frequency of admissions to hospitals and emergency units as well as medical consultations in surgeries and outpatient clinics. The issue was investigated using the city of Cracow as an example. Attempts were made to find the connection between air pollution in the city of Cracow and the frequency of hospitalization and medical consultations of patients (registered in the city) due to lung and bronchial malignancy and cardiac dysrhythmia taking into account the data from the years 2010-2016 submitted by the Malopolska Regional Branch of the National Health Fund.
\end{abstract}

Keywords: air pollution, smog, low emission, morbidity

\section{INTRODUCTION}

Air pollutants monitoring, conducted in terms of assessing their harmfulness to human health in accordance with the EU and national regulations, includes the emission of 11 substances [Holnicki et al. 2014]. The study analyzes four selected substances which are especially prevalent in the Cracow agglomeration: suspended particulate matter $\left(\mathrm{PM}_{10}, \mathrm{PM}_{2.5}\right)$, sulfur dioxide $\left(\mathrm{SO}_{2}\right)$, nitrogen dioxide $\left(\mathrm{NO}_{2}\right)$ and carbon monoxide $(\mathrm{CO})$. Particular attention is paid to the threats arising from the emission of suspended particulate matter due to the fact that its concentration levels show the highest values among the four aforementioned toxicants and for this reason they arise public interest. For the conducted analyses, the basic thesis is that air polluted with low emission products poses a potential threat to the health of users and city dwellers. The low-emission sources such as urban transport and other transport pollution, the heating system of detached houses based on the combustion of coal and municipal waste, or lo- cal boiler rooms, rather than cogeneration plants, steel plants or other industrial plants, are the main source of air pollution in urban agglomerations [Bagieński and Jaskulska 2016; Report 2010; Petryk 2017a; Petryk 2017b]. This is related to the fact that the emission of pollutants from large industrial, heating, energy and transport sources is subject to numerous legal acts and to strict control, contrary to the uncontrolled practice of burning fuels and waste in household furnaces, which, however, is gradually normalizing [Juda-Rezler 2016]. For this reason, the emission of pollutants from low sources (so-called low emission) has a greater influence on air quality at the ground level of the atmosphere where fuels of low quality are often burnt, rather than from high sources (steel plants, cogeneration plants, etc.) where the quality of fuels used is incomparably higher, and in addition they are obligatorily equipped with high efficiency dust collectors [Juda-Rezler 2016]. In Poland, the most commonly used device for heating detached houses "is a boiler or coal furnace, less often a fireplace or a boiler fu- 
elled with wood or pallets or other types of biomass, whereas gas, oil boilers or electric heating are the rarest" [Degórska 2016]. The sources of low emission show multiple variations, depending on the chemical composition of pollutants and their emission intensity as well as the technical conditions of the emitter (height, diameter, etc.) [Juda-Rezler 2000].

\section{SOURCES AND IMPACT OF AIR POLLUTANTS ON HUMAN HEALTH}

The analysis of the related literature does not cast any doubt that the occurrence of some diseases is directly or at least indirectly associated with the pathogenic exposure to air pollution, especially in urban agglomerations. The relationship between the air pollutants and their impact on the health of inhabitants of urban agglomerations, especially metropolitan cities, concerns not only the morbidity of respiratory and immune system diseases or neurological symptoms, but also the prevalence of prematurity, spontaneous abortion, low birth weight and birth defects of newborns that lower their intellectual and immunological potential in subsequent developmental stages [Report on the state of health 2011].

Low emission of suspended particulate matter from the sources of municipal and household sector as well as from the so-called secondary emission related to the negligence of city cleanliness and the growing intensity of car transport is a real problem in Polish cities [Wnuka 2010]. Suspended particulate matter has its toxic impact on significant areas due to its cross-border nature caused by meteorological factors that may stimulate the spread of pollutants by air or restrict air ventilation in rural and urbanized areas [Kozłowska et al. 2011; Wnuka 2010]. Primary particulate matter emission comes from natural and anthropogenic sources, while the particulate matter generated as a result of chemical reactions becomes a secondary toxicant in the atmospheric air [Degórska 2016].

The number of research projects in which confirmation or exclusion of dependence between high concentrations of suspended particulate matter and the higher number diagnoses of specific diseases in people susceptible to short or longterm exposure to these toxicants is increasing. Among the effects of short-term exposure to the absorption of higher concentrations of suspended particulate matter by the body, acute responses of the respiratory system were found in individual age categories. Long-term exposure, even to relatively low concentrations of particulate matter, over many years leads to the development of chronic diseases, including cancer, especially lung cancer, as confirmed by the International Agency for Research on Cancer (IARC) [Skotak 2016].

The prenatal and perinatal exposure to toxic effects of suspended particulate matter may lead to fetal development disorders and cause perinatal complications; it also poses a higher risk of developing allergies, diabetes, asthma, nervous system diseases, etc. in a child's adult life [Skotak 2016]. The risk of recurrent pneumonia is even three times higher in the children whose mothers were exposed to high levels of PM2.5 during pregnancy [Warczyński 2016]. In etiopathogenesis of diseases, both the finest particulate matter fractions and the concentration of its individual constituent substances can be critical. It is believed that it is the content of hydrocarbons or transition metals exert more influence on the development of asthma than the total concentration of particulate matter [Jędrak, Badyda and Konduracka 2016]. Physical activity, which intensifies lung ventilation, exposes the people doing sport under the conditions of higher particulate matter concentration to the inhalation of higher content of the toxicant [Malec and Borowski 2016]. There is no safe level of concentration below which there are no adverse health effects of exposure to this toxicant [Skotak 2016].

The number of medical consultations as well as absenteeism in schools and workplaces rises when the concentration of suspended particulate is relatively low. Higher concentrations may determine the increase in the number of people being hospitalized as well as in the number of deaths [Skotak 2016]. Every year in Poland, more than fifteen times more people die from the diseases related to air pollution than from road accidents. This is estimated at forty-five thousand people a year [Warczyński 2016].

Black smog occurring in industrial areas in the winter is particularly dangerous for human health [Juda-Rezler 2000] due to the high concentrations of sulphur dioxide. Sulphur dioxide $\left(\mathrm{SO}_{2}\right)$ of anthropogenic origin is emitted from municipal and household sources, and above all from the energy and industrial sources associated with 
the extraction, processing and combustion of fossil fuels, in particular, hard coal in Poland [Kordylewski 2008]. Exposure to high concentrations of the colourless gas characterized by a choking odour is fraught with a high risk of airway damage [Kostrz and Satora 2017].

In the case of nitrogen dioxide $\left(\mathrm{NO}_{2}\right)$, there is an upward trend in its anthropogenic emission from urban transport sources, with a noticeable reduction in the production of nitrogen oxides in the energy industry [Juda-Rezler 2000]. On the one hand, this is due to the increasing share of cars in urban transport, on the other, it results from the use of modern technologies in the power industry [Juda-Rezler 2000]. Exhaust fumes constitute the main source of carbon monoxide (CO) emission although combustion of fuels in the municipal and household sector, accounting for nearly $50 \%$ of its national emissions plays also a significant role [Zakrzewski 1995; Juda-Rezler 2000; Hławiczka 2008].

\section{AIR POLLUTION IN CRACOW}

Road transport is a critical source of particulate matter emission. Not only is the dust caused by the combustion of fuels in car engines, but also by the wear of brake pads and the abrasion of tires and road surfaces, including re-suspension, i.e. re-lifting of road dust during road traffic [Degórska 2016]. According to the data of the Department of Municipal Economy and Environmental Protection of the Municipal Office of Cracow, collected on the basis of vehicular traffic measurements, approximately 40,000 vehicles pass through Cracow through transit traffic every day, and the total number of people entering the city daily amounts to 246 thousand. The most traffic-laden are: Kościuszko barrage, the Dębnicki
Bridge, as well as ul. Wielicka and Zakopiańska [“Gazeta Krakowska” 2017].

It was estimated that several hundred people die due to air pollution in Cracow per year. "The average number of avoidable deaths per year was estimated for 2001 in relation to the level of pollution reduction (average annual PM2.5). The reduction to the level of $25 \mu \mathrm{g} / \mathrm{m}^{3}$ would decrease the number of deaths on average by 232 , to the level of $20 \mu \mathrm{g} / \mathrm{m}^{3}$ by 362 , to the level of $15 \mu \mathrm{g} / \mathrm{m}^{3}$ by 492 , and to the level of $10 \mu \mathrm{g} / \mathrm{m}^{3}$ (WHO recommendation) by 612 . In addition, it was estimated that a statistical resident of Cracow would live one year longer, on average, if the mean annual concentration of particulate matter PM2.5 could be reduced to $15 \mu \mathrm{g} / \mathrm{m}^{3 "}$ [bip.malopolska.pl 2017].

The data from the Krakow Smog Alert indicated that the daily dose of benzo[a]pyrene absorbed by residents of Krakow during the year 2011 corresponded to the smoking an average of seven cigarettes [Pankowska, Gorczyca 2015].

The measurements carried out in the air quality control stations at the main communication routes in Cracow showed that the permissible level of PM10 particulate matter concentration had been exceeded in the years 2010-2015 (Table 1). Despite the exceedance of standards, a decrease in the concentration of average annual PM10 in the analyzed five-year period was observed at all measuring points.

In the same period, the values of average annual PM 2.5 concentration also exceeded the permissible standards (Table 2). As in the case of PM 10, a downward trend of PM 2.5 concentrations was noticeable in the years 2011-2015. In 2016, in the Cracow agglomeration, more than 35 exceedances of the permissible standard of PM10 concentrations were observed at all monitoring stations within 24-hour period (Table 3).

Table 1. The concentration of average annual PM 10 at air quality monitoring stations in Cracow in the years 2011-2015

\begin{tabular}{|l|c|c|c|c|c|}
\hline \multirow{2}{*}{$\begin{array}{c}\text { Location } \\
\text { of the measuring station }\end{array}$} & \multicolumn{5}{|c|}{ Concentration of average annual PM 10 [ $\left[\mathrm{\mu g} / \mathrm{m}^{3}\right]$} \\
\cline { 2 - 6 } & 2011 & 2012 & 2013 & 2014 & 2015 \\
\hline Ul. Bujakowa & 54 & 53 & 44 & 46 & 45 \\
\hline Ul. Bulwarowa & 77 & 66 & 60 & 64 & 68 \\
\hline Al. Krasińskiego & 63 & 51 & 49 & 49 & 52 \\
\hline
\end{tabular}

Source: Prepared on the basis of: Annex No. 1 to Resolution No. XXXII / 451/17 of the Regional Assembly of the Malopolska Region of 23 January 2017. 
Table 2. The concentration of average annual PM 2.5 at air quality monitoring stations in Cracow in the years 2011-2015

\begin{tabular}{|c|c|c|c|c|c|}
\hline \multirow{3}{*}{\begin{tabular}{|c|} 
Location \\
of the measuring station
\end{tabular}} & \multicolumn{5}{|c|}{ Concentration of average annual PM $2.5\left[\mu \mathrm{g} / \mathrm{m}^{3}\right]$} \\
\hline & \multicolumn{5}{|c|}{ Permissible level (since 2005):25 $\mu \mathrm{g} / \mathrm{m}^{3}$, (since 2020): $25 \mu \mathrm{g} / \mathrm{m}^{3}$} \\
\hline & 2011 & 2012 & 2013 & 2014 & 2015 \\
\hline Ul. Bujakowa & 37 & 41 & 33 & 33 & 34 \\
\hline Ul. Bulwarowa & 42 & 38 & 35 & 32 & 33 \\
\hline Al. Krasińskiego & 55 & 47 & 44 & 45 & 44 \\
\hline
\end{tabular}

Source: Prepared on the basis of: Annex No. 1 to Resolution No. XXXII / 451/17 of the Regional Assembly of the Malopolska Region of 23 January 2017.

Table 3. List of stations in the area of the Agglomeration of Cracow in 2016 in which there were more than 35 exceedances of levels of permissible concentrations of PM10 - an average of 24 hours (D24) and the number of cases of exceedances at individual stations (health protection)

\begin{tabular}{|c|l|c|c|}
\hline \multirow{2}{*}{ Zone name } & \multicolumn{1}{|c|}{ Station code } & $\begin{array}{c}\text { Number of exceedances } \\
\text { D24 }\end{array}$ & $\begin{array}{c}\text { The maximum daily } \\
\text { concentration value * } \mu \mathrm{g} / \mathrm{m}^{3}\end{array}$ \\
\hline \multirow{5}{*}{$\begin{array}{c}\text { The Agglomeration } \\
\text { of Cracow }\end{array}$} & Aleje Krasickiego & 165 & 329 \\
\cline { 2 - 4 } & Ul. Bujaka & 78 & 295 \\
\cline { 2 - 4 } & Ul. Bulwarowa & 74 & 275 \\
\cline { 2 - 4 } & Ul. Dietla & 118 & 314 \\
\cline { 2 - 4 } & Os. Piastów & 69 & 203 \\
\cline { 2 - 4 } & Złoty Róg & 85 & 231 \\
\hline
\end{tabular}

* The number of stations from which the results were used in the assessment for 2016

Source: own study based on the Air quality assessment in zones in Poland for 2016

\section{AIR POLLUTION AND INCIDENCES OF THE RESPIRATORY SYSTEM CANCERS, BRONCHI AND LUNGS CANCERS AS WELL AS CARDIAC DYSRHYTHMIA IN CRACOW}

Malignancies caused by environmental pollution, mainly air pollution, constitute nearly $2 \%$ of the diagnosed malignancies, although this index is even higher in the populations of the Małopolskie and Silesia region [Kapka et al. 2009]. In the urban population, lung cancer is diagnosed more often than in the rural population [Gładka and Zatoński 2016]. In the population of Cracow, this risk increases by $4.5 \%$ in the male group and $10.5 \%$ in the female group [Kapka et al. 2009]. Air pollution is a critical factor in the development of lung cancer, which is second only to smoking [Gładka and Zatoński 2016, Gładysz et al. 2010]. It is believed that the abnormal concentration of nitrogen dioxide has the largest pathogenic impact on the occurrence of lung cancer [Gładka and Zatonski 2016]. People exposed to prolonged exposure of suspended particulate matter in the air are also highly susceptible due to the fact that the period of lung cancer development under the conditions of intense particulate matter exposure is by four years shorter than in the case of other carcinogenic substances that pollute the air [Cembrzyńska and in 2012]. Household stoves, in which plastic wastes are burnt, are one of the main emitters of toxicants with a mutagenic and cytotoxic effect [Jędrak et al. 2016].

In the years 2010-2016, men comprised the largest group of the patients treated for malignancy in Cracow; in hospital wards, inpatient emergency departments and admission rooms, the share of men accounted for $62 \%$ of the total number of patients treated, while in outpatient clinics it amounted to $60 \%$ of the total number of consulted patients (Table 4). Analyzing the diversity of the age structure, it should be stated that men dominated in all age categories. In the years 2011, 2012, 2015 and 2016, no female in the age range of 0-34 applied for treatment in hospital wards, inpatient emergency departments and admission rooms, whereas in outpatient clinics such a situation occurred in 2016. In the male group, the patients in the age range of $0-34$ were not treated in hospital wards and in admission rooms in the years 2014 and 2016. There was a noticeable disproportion, both in the female and male group between the number of people in the age range of 0-34 and the total number of people ben- 
Table 4. List of patients by sex and age living Cracow treated in the years 2010-2016 for the respiratory system cancers, bronchial and lung malignancy

\begin{tabular}{|c|c|c|c|c|c|c|c|c|c|c|c|c|c|c|c|c|c|c|}
\hline \multirow{3}{*}{$\begin{array}{l}\text { Name of } \\
\text { the disease } \\
\text { entity }\end{array}$} & \multirow{3}{*}{ Year } & \multirow{3}{*}{$\begin{array}{l}\text { Total number } \\
\text { of medical } \\
\text { services }\end{array}$} & \multicolumn{8}{|c|}{$\begin{array}{l}\text { Hospital departments with the inpatient } \\
\text { emergency departments and the admis- } \\
\text { sion room }\end{array}$} & \multicolumn{8}{|c|}{$\begin{array}{c}\text { Outpatient specialist care clinics contracted } \\
\text { by Krakow's hospitals }\end{array}$} \\
\hline & & & \multicolumn{2}{|c|}{$\begin{array}{c}\text { age } \\
0-34\end{array}$} & \multicolumn{2}{|c|}{$\begin{array}{c}\text { age } \\
35-64\end{array}$} & \multicolumn{2}{|c|}{ age $65+$} & \multicolumn{2}{|c|}{ age $\mathrm{O}+$} & \multicolumn{2}{|c|}{$\begin{array}{l}\text { age } \\
0-34\end{array}$} & \multicolumn{2}{|c|}{$\begin{array}{c}\text { age } \\
35-64\end{array}$} & \multicolumn{2}{|c|}{ age 65+ } & \multicolumn{2}{|c|}{ age $\mathrm{O}+$} \\
\hline & & & $\mathrm{M}$ & $\mathrm{F}$ & $M$ & $\mathrm{~F}$ & $M$ & $\mathrm{~F}$ & $M$ & $\mathrm{~F}$ & $M$ & $\mathrm{~F}$ & $M$ & $\mathrm{~F}$ & M & $\mathrm{F}$ & $M$ & $\mathrm{~F}$ \\
\hline \multirow{7}{*}{$\begin{array}{c}\text { C-34 } \\
\text { (Bronchial } \\
\text { and lung } \\
\text { malignancy) }\end{array}$} & 2010 & 4684 & 2 & 1 & 127 & 67 & 209 & 94 & 338 & 162 & 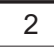 & 2 & 234 & 165 & 352 & 174 & 588 & 341 \\
\hline & 2011 & 4704 & 1 & 0 & 135 & 69 & 193 & 105 & 329 & 17 & 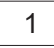 & 2 & 218 & 162 & 353 & 188 & 572 & 352 \\
\hline & 2012 & 5495 & 2 & 0 & 124 & 67 & 210 & 115 & 336 & 182 & 4 & 2 & 229 & 163 & 366 & 215 & 599 & 380 \\
\hline & 2013 & 232 & 1 & 2 & 100 & 80 & 190 & 120 & 291 & 202 & 1 & 2 & 19 & 181 & 371 & 228 & 91 & 411 \\
\hline & 2014 & 5443 & 0 & 1 & 96 & 74 & 230 & 144 & 326 & 219 & 2 & 3 & 200 & 157 & 402 & 266 & 604 & 426 \\
\hline & 2015 & 5246 & 2 & 0 & 96 & 70 & 202 & 127 & 300 & 197 & 2 & 1 & 194 & 157 & 406 & 271 & 602 & 429 \\
\hline & 2016 & 5697 & 0 & 0 & 92 & 65 & 217 & 161 & 309 & 226 & 1 & 0 & 177 & 137 & 430 & 322 & 608 & 459 \\
\hline
\end{tabular}

Source: Own study based on data from the Malopolska Provincial Branch of the National Health Fund in Krakow obtained applying the public information act (correspondence of 6 July 2017).

efiting from medical services from the other two age ranges of 35-64 and 65+. The morbidity of bronchial and lung malignancies then mainly affected the people over 35 years of age, with a significant predominance of male patients; however, the highest morbidity rate was revealed in people over 65 years of age. In the years 2010-2016, the percentage share of male patients in the age range of 0-34 in the group of all male patients treated for malignant lung cancer and bronchial carcinoma in hospital wards and admission rooms amounted to $0.36 \%$, whereas in outpatient clinics to $0.31 \%$. On the other hand, the percentage share of men in the age range of $65+$ treated in the analyzed six-year period in hospital wards and admission rooms accounted for $65 \%$, and in outpatient clinics $64 \%$.

Analyzing the number of medical services provided to patients with bronchial and lung cancer in the reporting period, it should be noted that in comparison to 2010 , by 2016 the number of benefits had increased by 1013 . In the years 2010-2012, there was an upward trend, which in the next three years was at constant level. Since 2015, there has been a visible, dynamic increase in the number of medical services (Table 4).

The research confirmed that even a shortterm exposure to suspended particulate matter may cause electrophysiological changes in the heart that result in cardiac dysrhythmia and intensify susceptibility to this type of heart anomalies [Kowalska and Kocot 2016]. In addition to cardiac dysrhythmia, the consequences of being exposed to air pollution in various time ranges, especially to suspended particulate matter and carbon dioxide, are also indicated by cardiac insufficiency and ischemic heart disease [Kowalska and Krzych 2007; Malec and Borowski 2016]. Obese and older people (over 65 years of age), patients treated for obstructive pulmonary disease or diabetes, and those with chronic respiratory and cardiovascular diseases are listed in the high-risk group [Jędrak et al. 2016 Kowalska and Kocot 2016]. A long-term exposure to lowemission toxicants is also a pathogenic factor of the inflammatory system in young healthy people [Annex No. 1 to Resolution No. XXXII/451/17 of the Regional Assembly of the Malopolska Region of 23 January 2017]. Excessive concentrations of smog toxicants may be responsible for a larger number of urgent hospitalizations caused by the onset or exacerbation of cardiovascular disease symptoms [Kowalska and Krzych 2007]. "It was also proven that the increase in the concentration of PM2.5 by only $10 \mathrm{ug} / \mathrm{m}^{3}$ in a short time $(<24$ hours $) \mathrm{r}$ the relative risk of cardiovascular deaths from $0.4 \%$ to $1.0 \%$ " [Jędrak, Badyda and Konduracka 2016].

In the period from 2010 to 2016 (Table 5), women constituted the largest group of patients treated in Cracow due to dysrhythmias in both hospital wards, inpatient emergency departments and admission rooms ( $65 \%$ of total patients), as well as in outpatient clinics (69\%). In the distribution of the age structure, there was a strong dominance of women in all age ranges. In the group of men treated in hospital wards, inpatient emergency departments and in admission rooms, patients over 65 comprised the largest group (37\%). In turn, in the group of men treated in outpatient clinics, the majority of patients were in the age range of $0-34$ (48\%). A small number of men aged $65+$ who had medical consultations due to heart rhythm disorders in outpatient clinics (15\%) was evident. 
Table 5. List of patients by sex and age living Cracow treated in the years 2010-2016 for cardiac dysrhythmia

\begin{tabular}{|c|c|c|c|c|c|c|c|c|c|c|c|c|c|c|c|c|c|c|}
\hline \multirow{3}{*}{$\begin{array}{l}\text { Name of } \\
\text { the disease } \\
\text { entity }\end{array}$} & \multirow{3}{*}{ Year } & \multirow{3}{*}{$\begin{array}{c}\text { Total } \\
\text { num- } \\
\text { ber of } \\
\text { medical } \\
\text { servi- } \\
\text { ces }\end{array}$} & \multicolumn{8}{|c|}{$\begin{array}{l}\text { Hospital departments with the inpatient } \\
\text { emergency departments and the admission } \\
\text { room }\end{array}$} & \multicolumn{8}{|c|}{$\begin{array}{l}\text { Outpatient specialist care clinics contracted } \\
\text { by Krakow's hospitals }\end{array}$} \\
\hline & & & \multicolumn{2}{|c|}{ age $0-34$} & \multicolumn{2}{|c|}{ age $35-64$} & \multicolumn{2}{|c|}{ age $65+$} & \multicolumn{2}{|c|}{ age $\mathrm{O}^{+}$} & \multicolumn{2}{|c|}{ age $0-34$} & \multicolumn{2}{|c|}{ age $35-64$} & \multicolumn{2}{|c|}{ age $65+$} & \multicolumn{2}{|c|}{ age $\mathrm{O}+$} \\
\hline & & & $M$ & $\mathrm{~F}$ & M & $\mathrm{F}$ & $M$ & $\mathrm{~F}$ & $M$ & $\mathrm{~F}$ & $M$ & $\mathrm{~F}$ & $M$ & $\mathrm{~F}$ & $M$ & $\mathrm{~F}$ & $M$ & $\mathrm{~F}$ \\
\hline \multirow{7}{*}{$\begin{array}{l}\text { R00 (car- } \\
\text { diac ar- } \\
\text { rhythmia) }\end{array}$} & 2010 & 414 & 18 & 19 & 14 & 35 & 13 & 32 & 45 & 86 & 25 & 54 & 21 & 60 & 2 & 17 & 48 & 131 \\
\hline & 2011 & 388 & 20 & 32 & 18 & 42 & 16 & 37 & 54 & 111 & 25 & 33 & 10 & 56 & 7 & 14 & 42 & 103 \\
\hline & 2012 & 457 & 17 & 33 & 23 & 42 & 30 & 54 & 70 & 129 & 32 & 39 & 16 & 52 & 5 & 15 & 53 & 106 \\
\hline & 2013 & 587 & 37 & 48 & 34 & 84 & 37 & 58 & 108 & 190 & 27 & 38 & 14 & 61 & 9 & 22 & 50 & 121 \\
\hline & 2014 & 590 & 35 & 50 & 42 & 70 & 45 & 69 & 122 & 189 & 32 & 47 & 26 & 65 & 11 & 15 & 69 & 127 \\
\hline & 2015 & 683 & 35 & 53 & 43 & 116 & 44 & 87 & 122 & 256 & 22 & 43 & 28 & 76 & 9 & 22 & 59 & 141 \\
\hline & 2016 & 611 & 37 & 67 & 30 & 70 & 53 & 76 & 120 & 213 & 24 & 31 & 28 & 71 & 17 & 32 & 69 & 134 \\
\hline
\end{tabular}

Source: Own study based on data from the Malopolska Provincial Branch of the National Health Fund in Krakow obtained applying the public information act (correspondence of 6 July 2017).

Among the women subject to treatment in hospital wards and admission rooms, female patients in the age range of 35-64 comprised the largest group (39\%); a similar trend was in outpatient clinics $(51 \%)$. In the analyzed six-year period, a relatively constant upward tendency in the number of medical services provided to the patients with arrhythmias was noticed. In 2016, the number increased by 197 services compared to 2010 .

\section{CONCLUSIONS}

1. In the years 2010-2016, men constituted the largest group of patients treated for malignancy in Cracow. The morbidity of lung and bronchial malignancy mainly concerned the people over 35 years of age, with a significant majority of male patients. The highest morbidity was found in people over 65 years of age.

2. In the period from 2010 to 2016, women constituted the largest group of patients treated for dysrhythmias. In the distribution of the age structure, strong dominance of women in all age ranges was visible at that time.

3. The latest literature data show that the human exposure to suspended particulate matter (PM10 and PM2.5), sulfur dioxide $\left(\mathrm{SO}_{2}\right)$, nitrogen dioxide $\left(\mathrm{NO}_{2}\right)$ and carbon monoxide (CO) is associated with an increased risk of cardiac arrhythmia, lung and bronchial malignancy as well as asthma.

4. The analysis of the state of air pollution: PM10 and $\mathrm{PM} 2.5, \mathrm{SO}_{2}, \mathrm{NO}_{2}, \mathrm{CO}$ showed that there were unfavorable weather conditions in the city of Cracow, resulting in long-term excessive concentrations of low-emission toxicants.

\section{REFERENCES}

1. Bagieński Z., Jaskulska J. 2016. Limiting the impact of heat supply sources on air quality in areas of intensive low-rise buildings. Atmospheric air. Quality, health, protection. Wroclaw University of Technology. Wroclaw [in Polish].

2. Cembrzyńska J., Krakowiak E., Brewczyński P.Z. 2012. Air pollution with suspended particulate matter PM10 and PM 2.5 in conditions of strong anthropopressure taking of the city of Sosnowiec as an example. Medycyna Środowiskowa, 15(4), 31-38 [in Polish].

3. Cholewiński M., Kamiński M., Pospolita W. 2016. Threats to human health and life from the use of selected fuels in individual heating systems. Kosmos, Problemy Nauk Biologicznych, 65(4), 477-486 [in Polish].

4. Czornik M. 2004. City. Economic aspects of functioning. Publisher of the University of Economics in Katowice [in Polish].

5. Degórska A. 2016. Sources of air pollution with particulate matter. In: K. Juda-Rezler and B. Toczko (Eds). Fine particulate matter in the atmosphere. Compendium of knowledge about air pollution with suspended particulate matter in Poland. Library of Environment Monitoring. Environmental Protection Inspection. Warsaw, pp. 22-26 [in Polish].

6. Gazeta Krakowska, 2017. http://www.gazetakrakowska.pl/motofakty/na-drogach/a/do-krakowawjezdza-dziennie-cwierc-miliona-samochodowraport,12788292/ (retrieved on 18 Februrary 2018).

7. Gładka A., Zatoński T. 2016. The influence of air pollution on respiratory diseases. Kosmos. Problemy Nauk Biologicznych, 65(4), pp. 573-582 [in Polish].

8. Gładysz J., Grzesiak A., Nieradko-Iwanicka B., Borzęcki A. 2010. The impact of air pollution on the health and life expectancy of people. Problemy Hi- 
gieny i Epidemiologii, 91(2), 178-180 [in Polish].

9. Hławiczka S. 2008. Heavy metals in the environment. Institute for Ecology of Industrial Areas Ekonomia i Środowisko Publishing Houe, Białystok [in Polish].

10. Holnicki P., Kałuszko A., Stankiweicz K. 2014. Supporting management of air qualityin an urban area. Współczesne Problemy Zarządzania, No 1, 26-27 [in Polish].

11. HWO, 2016. HWO's Global Urban Ambient Air Pollution Database. Update 2016. http:/www. who.int/phe/health topics/en/ (retrieved on $7 \mathrm{Au}-$ gust 2017).

12. Jarosiński J. 1996. Clean combustion techniques. Scientific and Technical Publisher, Warsaw [in Polish].

13. Jędrak J., Badyda A.J. Konduracka E. 2016. The impact of air pollution on human health. Sustainable cities. Życie w zdrowej atmosferze, pp. 87-96, [in Polish].

14. Jędrak J., Konduracka E., Badyda A.J., Dąbrowski P. 2016. The impact of air pollution on health. Krakow Smog Alert. Krakow. [in Polish].

15. Juda-Rezler K. [2000]. Environmental Impact of Air Pollution. Warsaw University of Technology Publishers, Warsaw [in Polish].

16. Juda-Rezler K. 2016. Fine particulate matter in the atmosphere. Compendium of knowledge about air pollution with suspended particulate matter in Poland.K. Juda-Rezler and B.Toczko (eds). Library of environment monitoring. Environmental Protection Inspection. Warsaw, pp. 9-10 [in Polish].

17. Kapka L., Zemła B.F., Kozłwoska A., Olewińska E., Pawlas N. 2009. Air quality and the morbidity of lung cancer in selected cities and counties of the Silesia Voivodship. Przegląd Epidemiologiczny, No 63, 439-444 [in Polish].

18. Klich J. 2017. Institutional potential of health care in cities. Part III. Contemporary problems related to urban development. In: M. Kudłacz, J. Hausner (Eds). Funkcjonowanie metropolii w Polsce-Gospodarka, Przestrzeń, Społeczeństwo. CeDeWu Publisher. Warsaw, pp. 237-253 [in Polish].

19. Kordylewski W. 2008. Combustion and Fuel. Wroclaw University of Technology. Wroclaw 2008 [in Polish].

20. Kostrz M., Satora P. 2017. Compounds responsible for air pollution. Inżynieria Ekologiczna, 18, 89-95 [in Polish].

21. Kowalska M., Krzych Ł. 2007. The influence of air polluted with particulate matter and sulfur dioxide on arterial blood pressure - current state of knowledge. Arterial Hypertension, 11(5), 435-442 [in Polish].

22. Kowlaska M., Kocot K. 2016. Short-term expo- sure to fine suspended particulate matter (PM2.5 and PM10) and the risk of arrhythmias and strokes. Postępy Higieny i Medycyny Doświadczalnej, No 70, 1017-1025 [in Polish].

23. Kozlowska-Szczęsna T. 2004. Influence of the atmospheric environment on health and human wellbeing. Institute of Geography and Spatial Organization, Warsaw [in Polish].

24. Kozłowska A., Olewińska E., Kolwska-Pawlak A., Pawlas N. 2011. The presence of mutagenic and cytotoxic pollutants in the PM10 and PM2.5 atmospheric aerosol fractions in the town of Sosnowiec. Medycyna Środowiska, 14(4), 21-33.

25. Kozłowska-Szczęsna T., Krawczyk B., Kuchcik M. 2004. Influence of the atmospheric environment on health and human well-being. Stanisław Leszczycki Institute of Geography and Spatial Organization State Academy of Sciences, Warsaw.

26. Lachman P. 2015. Causes of pollutant emission exceedances. Czysta Energia, No 12, 26-29.

27. Malec A., Borowski G. 2016. Particulate matter threats and air monitoring. Inżynieria Ekologiczna, vol. 50, 161-170 [in Polish].

28. Supreme Audit Office (NIK) 2014. Information on the results of the inspection. Air protection against pollution.Warsaw [in Polish].

29. Pałasz J.W. 2016. Low emission from coal combustion and methods of its reduction. Publisher of the Silesian University of Technology. Gliwice [in Polish].

30. Pankowska M., Gorczyca M. 2015. Air protection against pollution - why is it not possible to take a deep breath in Poland? Kontrola Państwowa, 3(362), 60-79 [in Polish].

31. State Environmental Monitoring, 2017. Air quality assessment in zones in Poland for 2016. Environmental Protection Inspection. Attachment A-D. Warsaw [in Polish].

32. Parysek J.J. 2015. The city in terms of system. Ruch prawniczy, ekonomiczny i socjologiczny. Ch. LXXVII/1, 28-40 [in Polish].

33. Petryk A. 2017a. Low-carbon Economy in the Municipality of Sucha Beskidzka. Journal of Ecological Engineering, 18(5), 144-150.

34. Petryk A. 2017b. Development of heating infrastructure as an opportunity to reduce low emission in Krakow. In: T. Kudłacz, P. Brańska (Eds) Studia Komitetu Przestrzennego Zagospodarowania Kraju PAN, vol. 174, 412-421 [in Polish].

35. Air quality plan for the Malopolska Region. Małopolska in a healthy atmosphere. Annex No. 1 to Resolution No. XXXII/451/17 of the Regional Assembly of the Malopolska Region of 23 January 2017. Office of the Marshal of the Małopolskie Voivodship 2017 [in Polish]. 
36. Report on the state of the environment in Poland, 2010. Chief Inspectorate for Environmental Protection, Library of Environment Monitoring [in Polish].

37. Report on the state of health in the Malopolskie Voivodship, 2011 [in Polish].

38. Regulski J. 1986. Town planning. State Economic Publisher. Warsaw [in Polish].

39. Schwartz J., Laden F., Zanobetti A. 2002. The concentration-response relations between PM25 and daily deaths. Environmental Health Perspectives, 110(10), $1025-1029$

40. Skotak K. 2016. The impact of suspended particulate matter on the environment. Fine particulate matter in the atmosphere. In: K. Juda-Rezler and B.Toczko (Eds). Compendium of knowledge about air pollution with suspended particulate matter in Poland. Library of Environment Monitoring. Environmental Protection Inspection. Warsaw, pp. 75-83 [in Polish].

41. Szymańska D. 2007. Urbanization in the world. PWN, Warsaw [in Polish].
42. Municipality of Krakow (UMK) 2014. Changes in the Study of conditions and directions of spatial development of the city of Krakow. Volume 1, Conditions, Krakow.

43. Justification of the resolution No XVIII/243/16 of Regional Assembly of the Malopolska Region of 15 January 2016 on the introduction, in the area of the Municipality of Krakow, of restrictions on the operation of installations in which combustion takes place on https://bip.malopolska.pl/ umwm,a, 1159347,uchwala-nr-xviii24316-sejmiku-wojewodztwa-malopolskiego-z-dnia-15-stycznia-2016-r-w-sprawie-wprowadz.html (retrieved on 12 November 2017).

44. Warczyński P. 2016. The impact of air quality on the health of Poles. Sustainable cities. Życie w zdrowej atmosferze, pp. 20-23 [in Polish].

45. Wnuka Z. 2010. Ecology and environmental protection: selected issues. Publishing House of the University of Rzeszów, Rzeszów [in Polish].

46. Zakrzewski S.F. 1995. Outline of environmental toxicology. PWN Warsaw [in Polish]. 